DOI https://doi.org/10.30525/978-9934-26-038-4-29

\title{
ОЦІНКА ЕФЕКТИВНОСТІ ТИМЕКТОМІЇ У ХВОРИХ НА ГЕНЕРАЛІЗОВАНУ ФОРМУ МІАСТЕНІЇ
}

\author{
Мінухін Д. В. \\ кандидат медичних наук, дочент, \\ доиент кафедри хірургї̈ № 1 \\ Харківський національний медичний університет \\ м. Харків, Украӥна
}

\section{Клімова О. М.}

доктор біологічних наук, професор,

завідувачка діагностичної лабораторії з імуноферментним та імунофлуоресцентним аналізом

Державна установа «Інститут загальної та невідкладної хірургї імені

B. T. Зайцева Національної академії медичних наук Украӥни»

м. Харків, Україна

\section{Свтушенко Д. О.}

доктор медичних наук,

професор кафедри хірургії № 1

Харківський начіональний медичний університет

м. Харків, Украӥна

Кудревич О. М.

кандидат медичних наук,

доцент кафедри хірургічних хвороб, оперативної хірургї

та топографічної анатомії

Харківський національний університет імені В. Н. Каразіна

м. Харків, Украӥна

\section{Кріцак В.В.}

лікар-хірург відділення торако-абдомінальної хірургії

Державна установа «Інститут загальної та невідкладної хірургії імені

В. Т. Зайцева Національної академії медичних наук України»

м. Харків, Україна

Міастенія являється аутоімунним захворюванням, патогенетичні механізми розвитку якого дуже тісно пов'язані з патологічними зміна- 
ми у тимусі $[2,4$, с. 2]. Необхідність видалення тимуса у хворих з прогресуючим перебігом генералізованої міастенії відмічається досить широким колом вітчизняних та закордонних дослідників $[1,3$, с. 2]. Не зважаючи на цей факт, до теперішнього часу недостатньо чітко розроблені критерії відбору пацієнтів до хірургічного лікування, схеми передопераційної підготовки та ведення післяопераційного періоду, профілактики післяопераційних ускладнень. Остаточно не доведена ефективність хірургічної складової в лікуванні міастенії [2, 3, 5, с. 2].

Мета роботи: оцінити ефективність тимектомії у пацієнтів з генералізованою формою міастенії шляхом аналізу ступеню компенсації міастенічної симптоматики у співвідношенні з віком пацієнтів, строками від маніфестації захворювання, характером морфологічних змін у тканині тимуса та імунологічними показниками.

Материалі і методи. Було проаналізовано стан 152 пацієнтів 3 генералізованною формою міастенії, які були прооперовані у відділенні торако-абдомінальної хірургії ДУ «Інститут загальної та невідкладної хірургії ім.В.Т.Зайцева НАМН України», що являється клінічною базою кафедри хірургії №1 Харківського національного медичного університету. На базі відділення функціонує регіональний міастенічний центр.

Діагноз генералізована форма міастенії було встановлено усім хворим на догоспітальному етапі враховуючі клінічнічну картину, дані електроміографічного дослідження, позитивну прозеринову пробу, дослідження рівня антитіл до ацетілхолінових рецепторів (АТ до АХР) та імунологічне дослідження. Зміни у передньому середостінні та тканині тимуса оцінювалися за допомогою спіральної комп'ютерної томографії (СКТ). За даними СКТ інволюція тимуса відмічена у 69(45,4\%) хворих, гіперплазія тимуса - 37(24,3\%) хворих, органоспецифічні пухлини тимуса (тимоми) - у 46(30,3\%) хворих. Серед обстежених пацієнтів було $119(78,3 \%)$ жінок та 33(21,7\%) чоловіків віком від 18 до 69 років. Більшість хворих - 78(51,3\%) була у віці від 25 до 45 років.

Показаннями до операції були: прогресуючий (прогредієнтний) перебіг захворювання із генералізацією процесу, наявність органоспецифічних пухлин тимуса.

Усім хворим оперативне втручання було виконано крізь продольний трансстернальний доступ. У разі пухлинного ураження тимуса виконувалась тимтимомектомія, усім іншим - виконана тимектомія. Широке видалення клітковини переднього середостіння виконувалося у всіх випадках.

Для оцінки результатів хірургічного лікування хворих на генералізовану форму міастенії нами була використана схема G.Keynes (1949) у модифікації нашої клініки: категорія А - повна клініко-функціональна 
компенсація (ПКФК), категорія В - частково стабільна клінікофункціональна компенсація (ЧСКФК), категорія С - часткова нестабільна клініко-функціональна компенсація (ЧНКФК), категорія D - відсутність ефекта, категорія Е - летальні випадкі.

Тривалість спостереження за хворими після операції склала від 12 місяців до 10 років. Перша оцінка результатів проводилась у термін 6 місяців після виконання операції.

Результати та їх обговорення. Оцінка результатів хірургічного лікування хворих на генералізовану форму міастенії проводилась станом на грудень 2020 року.

При первинному оцінюванні ефективності тимектомії хворі розподілилися наступним образом: категорія А - 48(31,6\%) пацієнтів; категорія В - 71(46,7\%) пацієнт; категорія C - 11(7,2\%) пацієнтів; категорія $\mathrm{D}$ - 14(9,2\%) пацієнтів; категорія C - 8(5,3\%) пацієнтів. Слід відмітити, що більш висока ступінь компенсації (категорія А і В) міастенічної симптоматики відмічена у хворих 3 інволюцією та гіперплазією тимуса - 76,2\%, а при тимомах - 63,5\%. Летальність склала 5,3\% (8 спостережень). Усі померлі пацієнти мали пухлини виделкової залози. Летальні випадки були пов'язані з розвитком міастенічних кризів у ранньому післяопераційному періоді.

Покращення стану спостерігалося у строки від 1 місяця до 1 року. Протягом означеного терміну деякі хворі переходили із категорії $\mathrm{C}$ до категорії В або із В до категорії А. У 4(2,6\%) пацієнтів через 12 місяців після операції відмічено посилення міастенічної симптоматики та вони перейшли із категорії В до категорії С. Особливо слід зазначити, що протягом усього дослідження не відмічено жодного випадку переходу пацієнтів із категорії А до категорій з нижчою компенсацією міастенічної симптоматики.

Також була проведена оцінка ефективності хірургічного лікування в залежності від тривалості захворювання та віку хворих. Протягом дослідження було виявлено, що повна та частково стабільна компенсація (категорії А і В) була досягнена у 79,5\% пацієнтів у вікової групі до 40 років та які були прооперовані протягом перших двох років від маніфестації захворювання.

Згідно результатам імунологічного дослідження у 72,6\% пацієнтів, яким була виконана тимектомія, клінічне покращення співпадало зі зниженням рівня антитіл до АХР (на фоні проведення патогенетичної терапії глюкокортикостироїдами в періопераційному періоді).

Висновки. Виконання тимектомії в комплексному лікуванні хворих на генералізовану форму міастенії дозволяє значно покращити результати лікування та поліпшити прогноз для життя за рахунок досягнення високого рівня клініко-функціональної компенсації. Повна та частково 
стабільна клініко-функціональна компенсація після тимектомії досягнена у 78,3\% пацієнтів. Відмічено безпосередній вплив морфологічних змін у тканині тимуса, термінів від маніфестації хвороби, віку пацієнтів та імунологічних показників на ступінь компенсації міастенічної симптоматики. Так більш висока ступінь компенсації відмічена у пацієнтів вікової групи до 40 років, які були прооперовані протягом перших 2 років від маніфестації захворювання, морфологічні зміни у яких відповідали інволюції або гіперплазії тимуса. Збіг факту зниження рівня антитіл до АХР та клінічного покращення дозволяють обгрунтовано рекомендувати виконання тимектомії у хворих на генералізовану міастенію.

\section{Література:}

1. Ветшев П.С., Аблицов А.Ю., Санадзе А.Г., Аблицов Ю.А., Крячко В.С., Лукьянов П.А., Магомедов Б.А. Мини-инвазивная хирургия в лечении больных с опухолями вилочковой железы. Онкология. Журнал им. П.А. Герцена. 2018. № 7(6). С. 5-11. DOI: $10.17116 /$ onkolog201870615

2. Оржешковський В.В. Сучасні підходи до діагностики та лікування міастенії гравіс. Неврологія. Кардіологія. 2011. № 9. С. 80-83.

3. Сигал Е.И., Сигал Р.Е., Сигал А.М., Бурмистров М.В., Потанин В.П. / Результаты видеоторакоскопической тимэктомии у пациентов с миастенией в сочетании с опухолевой патологией вилочковой железы. Поволжский онкологический вестник. 2015. № 2. C. 11-17.

4. Marulli G., Schiavon M., Perissinotto E. Surgical and neurologic outcomes after robotic thymectomy in 100 consecutive patients with myasthenia gravis. J. Thorac. Cardiovasc. Surg. 2013. № 145. P. 730-735.

5. Ruffini E., Guerrera F., Filosso P.L. Extended transcervical thymectomy with partial upper sternotomy: results in non-thymoma to us patients with myasthenia gravis. Eur J Cardiothorac Surg. 2015. № 48. P. 448-454. 